\title{
NÉVFÖLDRAJZI KUTATÁSOK - EGY CSALÁDNÉV FÖLDRAJZI ÉS TÖRTÉNELMI HÁTTERE
}

\author{
GÁBRIS GYULA \\ RESEARCH IN NAME GEOGRAPHY: THE GEOGRAPHICAL \\ AND HISTORICAL BACKGROUND OF A FAMILY NAME
}

\begin{abstract}
Language geography studies the spatiality of language. The examination of the Hungarian (geographic) place and personal names, tribe names as well as the family names, looks back about one and a half centuries. However, today's name geography has only emerged through digital databases and computer-aided cartography. Geographers, however, have generally not been very concerned with the spatial nature of linguistic phenomena. The following is an attempt to address this gap in the scholarship by focusing on the example of the Gábor family name and its name variants in geographic and historical contexts. Amongst Hungarian family names which have been inherited from the $15^{\text {th }}$ and $16^{\text {th }}$ centuries, Gábor is very common, and the oldest use of which was derived from the father's personal name. Such is the surname of Gábor, whose spatial distribution and temporal changes are presented in the study, with special attention to historical and political influences. The research was based on three databases: the first census of the country after it was completely liberated from Ottoman rule for the purpose of recording the taxpayer (1720); the Internet database of the First World War Loss List (RadixIndex), and data from Hungarian, Slovak, and Austrian web telephone books (no data from Romania and Serbia).
\end{abstract}

Keywords: language geography, name geography, family names

\section{Bevezetés - Gondolatok a névföldrajzról}

A nyelvföldrajz, mint vizsgálati módszer és szemlélet, a nyelv három fó dimenziója (térbeliség, időbeliség, társadalmiság) közül a térbeliséget vizsgálja, illetve az időbeliség és társadalmiság szempontját is a térbeliség felől közelíti meg. A nyelvtudomány egyik ága a nevekkel foglalkozik. A magyar névtudomány - melynek tradicionális része a magyar (földrajzi) hely- és személynevek, valamint a törzsnevek vizsgálata - története mintegy másfél évszázadra tekint vissza. A mai értelemben vett névföldrajz azonban csak néhány évtizedre. Hosszú ideig elkerülte ugyanis a kutatók figyelmét a nevek sokoldalú, területi összefüggésekre rávilágító vizsgálata. A térbeliség ábrázolásának eszköze a nyelvi adatokat és összefüggéseket is feltáró térképlapok sora, a nyelvatlasz. BENKő LORÁND (1949) a névföldrajzi kutatásokról szólva megállapította, hogy ,a régi magyar személynevek térbeli elterjedésének a kutatása az egész magyar nyelvterületre vonatkozó névatlaszok elkészítésében érheti el célját”. Azonban több mint fél évszázadot kellett arra várni, hogy a digitális adatbázisok és a számítógéppel támogatott kartográfia lehetôvé tegyék a magyar névföldrajzi kutatások jelenkori és történeti ágának a kibontakozását.

Napjainkban egyre több az olyan munka, amely szándékoltan lépi át a diszciplináris határokat, ezzel komoly hozzáadott értéket nyújt a különböző szakmáknak. Így van ez a névföldrajz múvelői körében is, akik meglehetősen kevesen vannak. Ennek a szakmai társaságnak vezető kutatója VÖRÖs FERENC, aki nyelvészként a családnevek földrajzi elterjedésének jellemzőivel foglalkozik immár több évtizede, s szervezi évek óta „A nyelvföldrajztól a névföldrajzig" címú konferenciasorozatot (N. FodOR J. 2014). Az elektronikusan tárolt adatbázisának létrehozásával (VöRÖs F. 2010) a 2009. január 1-jei állapot szerinti hazai lakosság teljes névsorának előfordulási adatai alapján megyei és települési bontásban mutatja be 
a családnevek térbeli tagolódását: az egyes (relatív) gyakorisági adatok mind megyei, mind településenkénti bontásban megjelennek a mai Magyarország térképén (VöRös F. 2014). Időközben a szerző az 1720-as országos összeírás levéltári digitalizált anyagára alapozva annak névanyagát is feldolgozta, amelyből az 1910-es közigazgatási megyehatárokra vetített történeti névföldrajzi kartogramokat hozott létre. A 2010-ben megindult Történeti magyar családnévatlasz (TMCsA) program egy történeti személynév-adatbázis összeállítása, melynek alapját az 1715-ös első országos összeírás adta, ami mellé 2012-től az öt évvel később készült adóösszeírás (1720) adatai is bekerültek (N. FODOR J. 2014). Az adatbázisok névföldrajzi felhasználása azonban még alig hogy elkezdődött, sok kiaknázatlan lehetőség van még benne.

A nyelvtudomány és a földrajztudomány kapcsolata messze nyúlik vissza a tudománytörténetben. Sokak számára kicsit furcsának túnhet ezt kimondani, hiszen napjainkban, földrajzos oldalról alig foglalkoznak olyan kutatási témával, amelyben a nyelvi jelenségek térbeliségén van a hangsúly. Az alábbiak erre vonatkozó kísérletet jelentenek, példaképpen a Gábor családnév, illetve névváltozatainak - Gábriel, Gábris - földrajzi és történelmi összefüggések keretében történő vizsgálatával.

Az öröklődő családnevek használata a 9-10. században Észak-Itáliában kezdődött, s onnan terjedt el először a volt Frank Birodalom területére, majd a keresztény világ egészére. Magyarországra a 14. században jutott el, s a 15. század végére már erősen elterjedt a családnevek használata (HAJDú M. 2010). A Hunyadiak korától a szabadok körében általános családnév használatról beszélhetünk. MEző A. (1970) szerint pedig a 15. század közepétôl már a jobbágyok körében is lehet öröklődő nevekkel számolnunk. SzABó I. (1954) néhány megye dézsmajegyzékeiből megállapította, hogy a 16. század elejétől (pontosabban 1522től) a magyar nyelvterületen általánosan kell számolnunk a családnevek öröklődésével.

Magyar eredetû családneveink között igen gyakori az egyházi vagy világi apanévből, illetve annak becézett változatából alakult típus. Egyik csoportjuk a személynévből lett családnév (Albert, Ambrus, Ádám, Benedek, Demeter... Zsigmond), amely a legrégebb idő óta előforduló típus. Külön csoportot alkotnak a keresztény eredetű (bibliai) nevek. Ezek nagy része minden végződés nélkül vált családnévvé. A keresztnévi eredetû, alapnévi (végződés nélküli) családnevek száma nem túl sok, de gyakori, és a mai Magyarországon 782510 személy, a magyar nevúek 12,4\%-a viseli. HAJDú M. (2010) véleménye szerint a családnevek kialakulásának idején (14-15. század) a zárt közösségek, pl. az önigazgatási joggal fölruházott székelység, vagy az őrségi magyarság körében az apanévi, elsősorban teljes keresztnévi családnevek a gyakoribbak. De az ilyen típusú családnevek földrajzi elterjedését, ennek sajátosságait, okait azonban még nem kutatták rendszeresen.

A Római Katolikus Egyház szenteket és boldogokat fölsoroló könyvében (Martyrologium Romanum), illetőleg a szertartáskönyvekben szereplő arkangyalok közül háromból - Gábor, Mihály és Rafael - lett keresztnév, majd apanévi eredetű magyar családnév. Jelen tanulmány tárgyát a Gábor családnév, illetve változatai képezik (a Mihály és Rafael névföldrajzi elemzését 1. GÁBRIS Gy. 2017). Jóllehet az elvándorlás, költözés megszokott dolog lehetett az évszázadok során, VöRÖs F. (2014) újabb kutatásai szerint azonban még napjainkig egyre felgyorsulva sem volt képes alapjaiban fölülírni a családnevek térbeli tagozódását. Az alábbiak e térbeli megoszlás kétségtelen időbeli változásait mutatják be, különös figyelemmel a történelmi, elsősorban politikai hatásokra.

\section{Módszerek}

A területi változások, a nevek - illetve a név hordozói - vándorlásának, elterjedésének vizsgálatához több időszakra vonatkozó adattömeg szükségeltetett. A kutatás alapjául 
három olyan adatbázis szolgált, amely egységes elvek szerint készülhetett és felölelte a régi Magyarország legnagyobb részét. Sajnos a területi homogenitás nem minden esetben volt megoldható, ezért az eredmények is esetenként eltérő bizonyosságúak. A csaknem 300 évet felölelő időszak három időkeresztmetszete a következő.

a) Az oszmán uralom alól teljesen felszabadult országnak az adózók számbavétele céljából 1715-ben megtartott, majd 1720-ban ennek helyesbítésére megismételt összeírása a népesség alapvetô forrása (DÁvid Z. 1957). Ekkor csak a külsőségekkel rendelkező jobbágyokat, zselléreket, taksát fizető nem nemeseket, szabadosokat kellett összeírni. A szegényebb réteg és más nem adózók az összeírásból kimaradtak. Nem vették fel a nemességet, a papságot és a tanítókat. Az összeírás nem terjedt ki az Erdélyi Fejedelemségre. Az összeírásnak több fogyatékossága volt - pl. sok megye nem tudta elkészíteni községeinek jegyzékét, vagy pontos kimutatást adni a nemességről. Az adatfelvétel gyakran nem helyszíni szemle alapján készült, és ritkán az is előfordult, hogy elfogadták a helyiek hamis vallomásait. Mindezek következtében sokan kivonták magukat az összeírás alól. Az 1720-as összeírás 178500 nevet tartalmazó adatbázisa elérhető az http://adatbazisokonline.hu/adatbazis/az-1720_-evi-orszagos-osszeiras webhelyen. A történeti demográfiai kutatások számításai alapján mintegy 3,8-4,3 millió főre becsülhetjük a történeti Magyarország lakosságát a 18. század elején (WELLMANN I. 1989; PÁLFFy G. 2009), így ez a létszám a korabeli Magyarország lakosságának nyilván csak egy kis részét, nagyjából 4,0-4,5\%-át adja ki.

b) A RadixIndex (Adatbázisok családfa- és helytörténet-kutatóknak) része az első világháborús veszteséglista (Verlustliste) internetes adatbázisa, amely 2018. szeptember 12-én kétszázezres frissítést kapott, és így a jelenleg elérhető csaknem 2 milliós tételével az adatbázis 80\% -on áll (még nagyjából 500000 adat hiányzik a teljes feldolgozottsághoz). Az adatok településenként állnak rendelkezésre, ezeket viszont könnyú megyei adatokká átszámítani. A RadixIndex tartalmaz másfajta adatokat - pl. iparosok, kereskedők összeírását 1891-ből - is, amelyeket egy esetben szintén számításba lehetett venni.

c) Napjaink névföldrajzi helyzete Kárpát-medencei szinten nehezen megítélhető. Eredetileg az internetes telefonkönyvek adatait célozta meg a feldolgozás. De csak a szlovák és az osztrák telefonkönyv adatai voltak teljes mértékben beszerezhetők, mert a magyar internetes telefonkönyvek 2014-ben még használhatók voltak ugyan, de később 50-nél több találat esetén nem adták ki az adatokat (egyet sem!). Romániából és Szerbiából szintén adathiánnyal állunk szemben. A szlovák adatok kényelmesebb feldolgozását a http:// www.cisarik.com/ webhely segítette elő. Magyarországon a 2009. január 1-jei állapotokat tükröző családnévállomány adatai - amelyet VöRÖs FERENC volt szíves rendelkezésre bocsátani - komoly segítséget jelentettek, azonban itt meg a bőség zavarával küszködünk. Ennek érzékeltetésére elegendő két szám összevetése: Szlovákiából 1087 Gábor adatát lehetett feldolgozni a telefonkönyvből, míg Magyarországon a népszámlás szerint 74303 személy viseli ezt a nevet. Világos, hogy az összehasonlítás komoly elővigyázatosságot kíván. Ezért az egyes nevek megyei százalékos adatait át kellett számolni a megye népessége szerinti létszámra, majd ez úgy lett körökkel ábrázolva, hogy a szlovákiai adatokkal arányaiban (fontos megjegyzés!) összevethető legyen. Az összehasonlítást tovább nehezítette, hogy az 1720. évi összeírásban és az I. világháborús veszteséglistában is csupán férfiak szerepeltek, ezért a szlovákiai, ausztriai és magyarországi telefonkönyvből is csak a férfiak lettek kigyújtve. A magyar népszámlálás adataiban azonban a lányok, feleségek, illetve özvegyek és a kisgyerekek is benne voltak, ami tovább torzította az összehasonlítás eredményét.

A fenti adatbázisok alapján a nevek területi elhelyezkedéséről kartogramok sorozata készült, s ezek elemezése volt a kiértékelés alapja, amelyet történelmi és földrajzi, elsősorban népességföldrajzi vonatkozások egészítettek ki. 


\section{Gábor}

Az apanévi magyar családnév a héber eredetû 'Isten embere' jelentésú Gábriél angyalnévre vezethető vissza. A magyar nyelvbe valószínúleg a görögből való latinosított Gabrinus névforma került, mert a Gabriel alakból nem magyarázható meg a Gábor név (HAJDú M. 2010). (A Gabrinusból a latin -inus végződés elhagyása után a lerövidült Gabr- névben a szó végének mássalhangzó-torlódása (-br) föloldódott az-o- bontóhanggal, s végül az első szótag magánhangzója a hangsúly hatására megnyúlt.) A mai alakjában a Gábor keresztnév, mint apának a neve, öröklődő családnévvé vált; jelentése Gábor nevú személy fia, leszármazottja. Elterjedtsége HAJDú M. (2010) szerint különösen Erdélyben, de általában a magyar nyelvterület keleti felében gyakoribb.

A görögből származtatható latinosított alapszó azonban felveti a kérdést, hogy a két „egyház” területi együttélése mikor, hogyan és milyen körülmények között, mely történelmi helyzetben (pl. az államalapítás előtt?) és miért a magyarok körében adott lehetôséget erre. Erre a választ valószínúleg nem a névföldrajzi kutatások adhatják meg.

Az 1720-as összeírás alapján (1/A ábra) kitûnik, hogy Erdély határvidékén - Erdélyből nincsenek adatok ebből az összeírásból (az 1886-os megyerendezés miatt került az 1910-es állapotokat mutató térképen Szolnok-Doboka és Hunyad megyébe néhány Gábor) Máramaros, Szilágy, Bihar megyékben és Szatmár keleti felében, valamint nyugaton Vas, délen Baranya megyékben regionálisan sűrüsödések vannak. Ezek az adatok alátámasztani látszanak HAJDÚ M. (2010) fenti véleményét, azzal kiegészítve, hogy a név délnyugaton (Ônrvidék) és Baranyában is eléggé gyakori. A Felvidéken csupán Hontban laktak nagyobb számban Gáborok. Fontosak a hiányok is, mert a Felvidéken Árva, Liptó, Turóc, Zólyom megyék üresek - lévén elsősorban szlovákok lakta vidék -, a Délvidéken pedig mind a négy megye üres, mert a török pusztítás után még nem kezdődött meg a magyarok visszatelepítése. Nehezen magyarázható viszont a magyarok lakta Borsod és Gömör megyékben a hiány (bár utóbbi esetben csak a megye déli része magyar). Más megyékben viszonylag egyenletesen, de alacsony számban vannak jelen.

Az első világháborús veszteséglista (Verlustliste) adatbázisából készült megyénkénti bontásban a 1/B ábra Fontos megjegyezni, hogy a Gáborok lakta 235 településből az 1910-es népszámlálás szerint 179 - vagyis a 76\% - magyar volt, vagy jelentős magyar kisebbséggel rendelkezett! Ebből az időből már vannak adatok Erdélyből is. Így a várakozásnak megfelelően elsősorban Székelyföld három megyéje - és a szomszédos Maros-Torda, a két

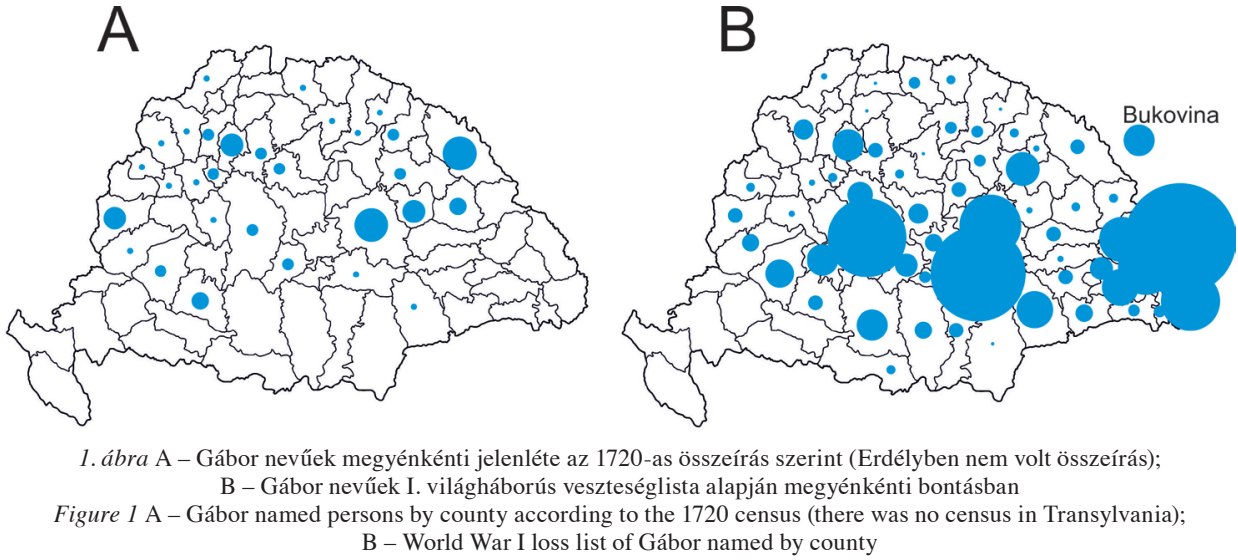


Küküllő megye meg a határon túli Bukovina - valamint a partiumi Arad, Bihar, Szatmár emelkedik ki, és meglepetésre Hunyad megye mutat még jelentős számot. Az ország közepén Pest (a Kiskunság), Tolna és Bács-Bodrog megyék nagy betelepítési hullámában már magyarok is részt vehettek. A Felvidéken Hont és Nyitra lakosai között lehettek nagyobb számban Gáborok. Regionális hiányok nyugaton Moson, Pozsony, Győr, Bars megyékben vannak, valamint a szlovákok lakta Turóc, Árva és Szepes, de Zólyom és Liptó is ide sorolható. Továbbra is magyarázatra vár, hogy miért nincsenek a magyar Gömörben? A Délvidéken a betelepítések következtében csak az elrománosodott Krassó-Szörény maradt üresen. Ez a térkép azt sugallja, amit többen megfogalmaztak már, hogy a keresztnévi eredetű családnevek elsősorban a székelység körében voltak gyakoriak (pl. HAJDú M. 2010), s onnan terjedt a török pusztítás után visszatelepített vidékekre; előbb a Partiumba, majd az ország közepére is.

Napjainkban a Gábor névföldrajzi helyzete kárpát-medencei szinten nehezen megítélhető. A 2006-os szlovák telefonkönyvben mintegy ezer személy adata volt felhasználható, az osztrák telefonkönyv szerint viszont csak hárman laktak Sopron, illetve egy Vas megye Burgenlandba eső részében. Romániát és Szerbiát illetóen adathiánnyal állunk szemben.

Szlovákiában (2. ábra) jelenleg nagy számban élnek a magyarok lakta jelenlegi határ mentén, pontosabban a 15. század végi nyelvhatáron belül (Kocsis K.-TÁTRAI P. 2013), valamint a történelmileg magyar Sáros és Abaúj megyékben, és a Vág mentén (Trencsén és Nyitra). Meglepó módon a szlovák jellegú Árva megyében is viszonylag gyakoriak; itt a megye 8 településén élnek, de ezekből 7 vlach jog alapján (l. később) a 16. században, vagy az után létesült. Komoly változást jelent, hogy a Szepességben mintegy 100 év alatt jelentősen megnőtt a számuk. A Gáborok megjelentek a jellegzetesen szlovák vidékeken, mint Turóc, Liptó (jóllehet itt valamennyien a megyeszékhelyen, Liptószentmiklóson élnek) és Zólyom megyék területén, de még hiányoznak Bars, Hont, Nógrád területén és Gömör északi részén. A nemzetiségi átrendeződést mutatja, hogy 2006-ban a Gáborok lakta 186 szlovákiai településből már csak 21 volt magyar többségú. A városba vándorlást jelzi, hogy az összesen 1087 Gábor 27,8\%-a, vagyis 302 fő négy nagyvárosban - Kassa, Pozsony, Eperjes és Poprád - él.

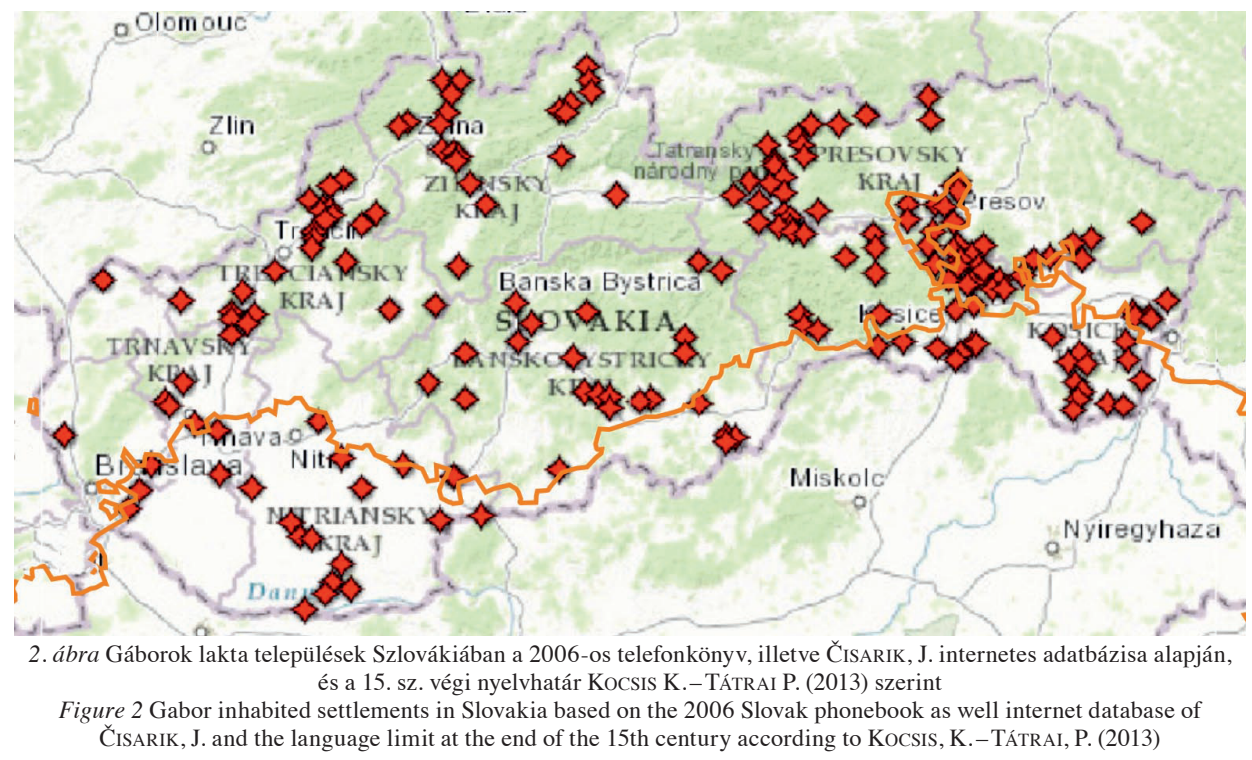


A 2001-es magyarországi népszámlálás 2009-ben közölt adatai (VöRös F. 2009) alapján hazánkban nehezebb kijelölni a súrúsödéseket (3/A ábra): Csongrád, Békés valamint Hajdú-Bihar megyék mellett az ország közepe (Pest / Budapest), és Tolna emelhető ki. Meglepetés, hogy a szlovák határ mentén csak a volt Hont megye maradványában jelentôsebb a számuk. A magyarországi 2009-es népszámlálás adatai a módszerek részben jelzett módon lettek felhasználva az összevont 3/B ábra térképének elkészítése céljából.

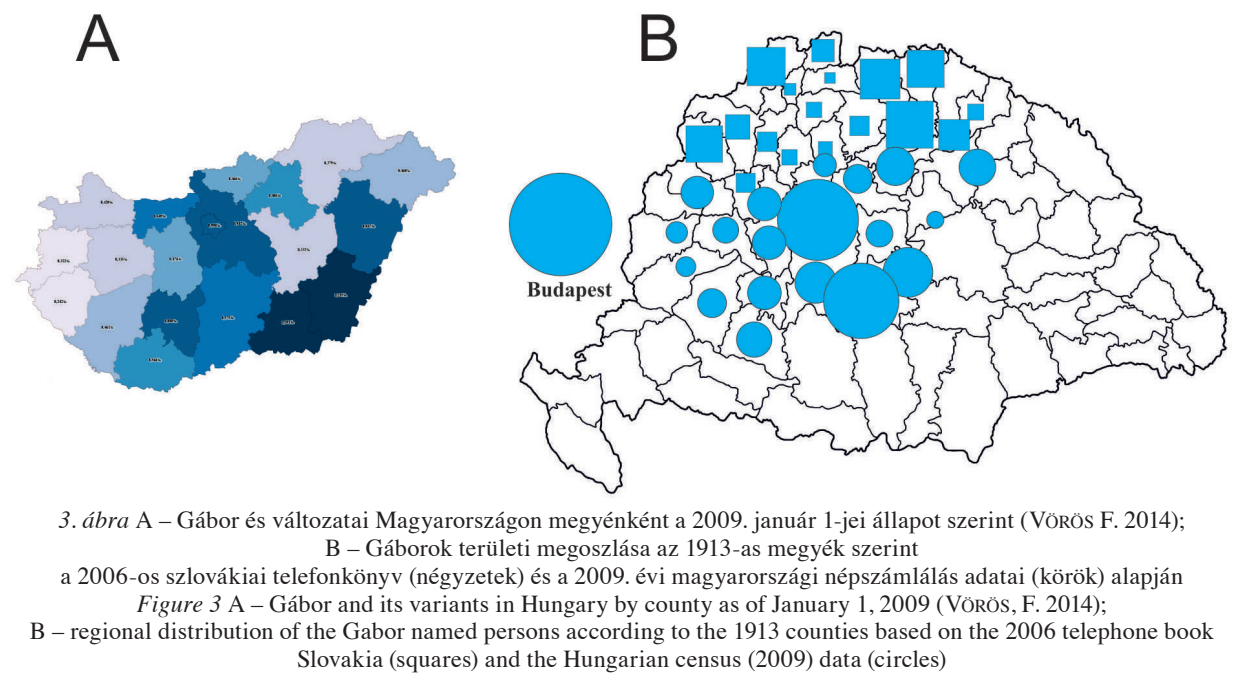

\section{Gábriel}

A Gábriel családnév Európában tőlünk nyugatra jellegzetes. Ott valószínúleg a héberből közvetlenül átvett latin szóból származik a név, így nálunk nem nevezhetó eredeti magyaros névadásnak (1. fent HAJDú M. 2010). Ez tükröződik Kárpát-medencei terjedésének csaknem 300 évet átfogó folyamatában is.

Az 1720-as összeírásban még csak az ország nyugati részén vannak jelen: elsősorban Sopron, kevésbé Vas, Győr és Moson megyékben (4/A ábra). Ez arra utal, hogy elsősorban a német anyanyelvúek között terjedt el a családnév.

Az I. Világháborús veszteséglista jól mutatja, hogy 1720 után megindult a név és ezzel együtt valószínúleg a németek terjedése kelet - Dunántúl, ott is főleg Tolna - valamint észak - Nyitra megye - felé (4/B ábra). Kiemelendő még Békés megye. Érdekes, hogy a szepesi és az erdélyi szászok között nincsenek Gábrielek. A Délvidék nagy betelepítési hulláma ebből a szempontból már tetten érhető, de nem jelentős. Ez azt jelzi, hogy a névviselők meghatározása összetettebb elemzést igényel.

A 2006-os szlovák telefonkönyv adatai szerint a Gábrielek itt is az ország nyugati részén, elsősorban Nyitra, Pozsony és még Komárom, Trencsén, Árva, illetve kevésbé Bars megyék területére koncentrálódnak; Közép- és Kelet-Szlovákiában viszont csak szórványosan fordulnak elő. A három időkeresztmetszet alapján egyértelmúen kirajzolódik a nyugati eredet; valószínúleg nem korai (pl. felvidéki és erdélyi szászok), hanem későbbi német betelepültek lehetnek. Az 5/A ábra térképe szerint több kisebb településben élnek, s főleg nyugaton. Ha azonban a lélekszámot is figyelembe vesszük (5/B ábra), kiderül, hogy jellemzően városlakók. Szlovákiában a Gábrielek 54\%-a öt városban él, mégpedig fôképpen 

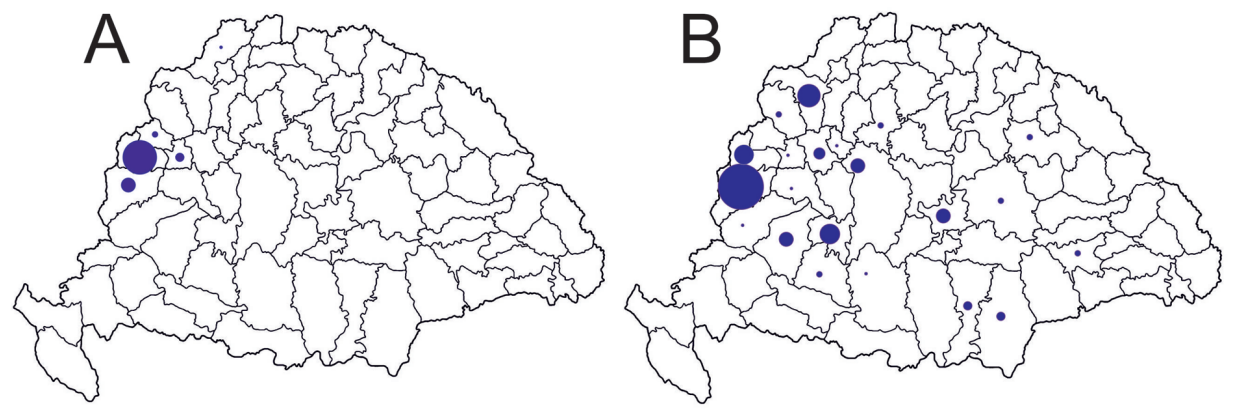

4. ábra A - Gábriel nevűek megyénkénti jelenléte az 1720-as összeírás szerint; B - Gábriel nevûek az I. világháborús veszteséglista alapján megyénkénti bontásban

Figure 4 A - Gábriel named persons by county according to the 1720 census (there was no census in Transylvania); B - World War I loss list of Gábriel named by county

A

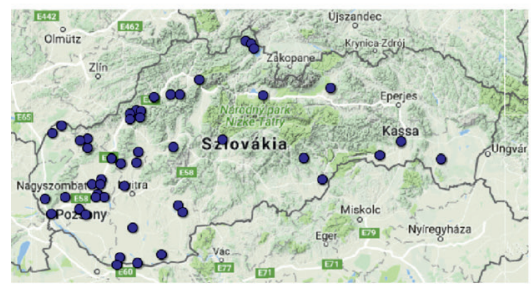

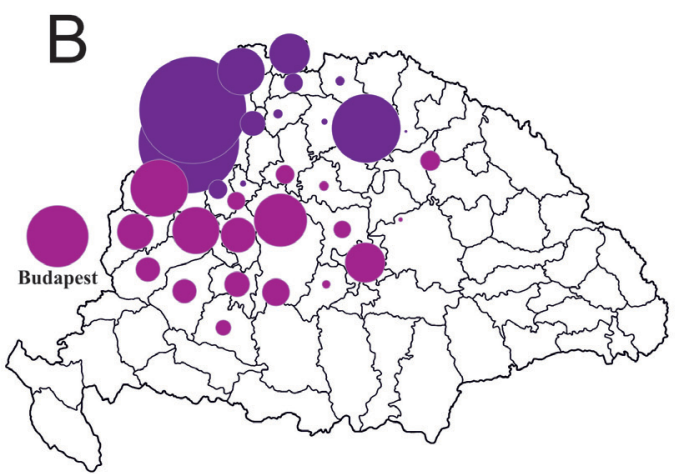

5. ábra A - Gábrielek lakta települések Szlovákiában (2006); B - Gábrielek megyénkénti megoszlása napjainkban Szlovákiában (sötétebb körök) és Magyarországon (világosabb körök)

Figure 5 A - Gabriel inhabited settlements in Slovakia (2006); B - Recent distribution of Gábriels by counties in Slovakia (darker circles) and in Hungary (lighter circles)

Pozsonyban, Nagyszombatban, Komáromban, Trencsénben és a szinte teljesen üres keleten egyedül Kassa városában.

A magyarországi népszámlálás 2009-es adataival összevont térkép (5/B ábra) is további terjedést sugall keletre és Budapestre (ez utóbbi a nagy- és fővárosokba történő áramlás világjelenségét húzza alá). Regionális sûrúsödés mutatkozik Nyugat- és Közép-Dunántúlon, Pest és Békés megyében. Regionális hiányok vannak Borsod-Abaúj-Zemplén megyében és általában a Tiszántúlon. Romániából ás Szerbiából nincsenek adataink.

\section{A Gábor név változatai}

A keresztnevet az emberek nagy része hivatalosnak és ridegnek érzi, különösen, ha családtagról, rokonról, ismerôsről van szó, ezért a neveket kedveskedő, becéző alakjukban is használják. A beceneveknek néha megkülönböztető szerepük is van, mivel a családon, a közösségen belül több azonos keresztnevú ember is létezhet. A Gábornak is több becenév változata van, mint a Gabó, Gabos és a Gábris, amelyekből hozzá hasonlóan családnevek váltak. 
Legritkább a Gabó, amelyből az 1720-as összeíráskor csupán egyet jegyeztek föl a Pöstyéntől délre fekvő Dubovány községből. Ma Szlovákiában nem ismert, Magyarországon is csak Felsőpakonyban szerepel egy személy a telefonkönyvben.

Sokkal gyakoribb a Gabos név, amelyből Szlovákiában 61 fordul elő 26, illetve - a városkörnyéki falvak összevonásai után - 14 településen a régi Trencsén, Árva, Sáros és Abaúj-Torna megyékben, ahol három kivételével mindegyikben előfordul Gábor, vagy Gábris nevű lakos is (esetleg mindkettő). Magyarországon 5 Gabos és 49 Gábos szerepel a telefonkönyvben. Utóbbiak jellemzően fővárosiak (12), illetve dunántúliak.

\section{A Gábris családnév kutatásának szubjektív indoklása - a név eredete}

Mint sokunkat felnőtt korunkban, engem is érdekelt a családom története, de később nevünk eredete iránt kezdtem érdeklődni, fel- és megjegyezve a véletlenül olvasottakat. Tulajdonképpen egy országbolydító esemény kapcsán jutottam el oda, hogy összegezni, sőt bővíteni kellene ismereteimet. Ez az esemény a világ legöregebb katonájának, Skultéty Lászlónak a szlovákiai Mojtínban rendezett újratemetése volt 2013 júniusában. Számomra ekkor derült ki, hogy az öreg katona születési neve Gábris László. Tovább sarkalt a kérdés tanulmányozására, hogy a helyi polgármester, Eva Gabrišová kijelentette: „Ladislav Škultéty-Gabriš végre hazatért, mi kértük a hazaszállítását, mert szlovák nemzetiségú volt, miként szülei és az utódai is. Nálunk az Osztrák-Magyar Monarchia idején legfeljebb a jegyző értett magyarul, mert ez színtiszta szlovák vidék". (Az egykori ezredkáplán, Sztaroczek Mihály 1865-ben megjelent visszaemlékezésében leírta, hogy a mélyen vallásos zászlótartó anyanyelvén kívül tökéletesen beszélt tótul és németül, a franciaországi hadjárat idején valamennyire franciául is megtanult, gyónni pedig csakis latinul járult a paphoz.)

A Gábris családnév a Gábor egyik változata (HAJDÚ M. 2010), mint annak tőrövidítéssel, valamint -is képzővel alkotott beceneve, és így válhatott apanévi eredetű családnévvé (KÁZMÉr M. 1993). Ez a családnév típus talán a legkorábbi magyar családnevek egyike. $\mathrm{Az}$ is kézenfekvő a fentiek alapján, hogy a mai Gábrisok nem vezethetók vissza egyetlen ösre, hanem többen viselhették a családnevek kialakulása idején, s ezek külön leszármazási vonalakat alkotnak.

Korábbi szórványos és egyáltalán nem rendszerezett ismereteim alapján előbb a Kisalföldön és hozzá kapcsolódó a Dunántúli-középhegységben találkoztam nagyobb számban ilyen nevekkel, majd később a Vág völgyében és Nyitra vidékén is előkerültek. A családnevek kialakulásának idején a szlovákban és a magyarban is megvolt a lehetősége a keresztségben elnyert puszta apanév mindenféle képző nélkül családnévvé válásának. Ugyanez a lehetőség fennállott a becenevek esetében is. Az etnikailag vegyesen lakott területeken, pl. a magyar-szlovák nyelvhatár mentén különös óvatosságra int bennünket az, hogy a Gábris családnév nemcsak magyar, hanem szlovák névképzéssel is létrejöhetett (VöRÖs F. 2006), hiszen mindkét nyelvben becéző funkciójú kicsinyítő képző szerepét töltötte be az -is (-iš) képző. Ilyenkor nehéz eldönteni, hogy az adott név melyik nyelvben keletkezhetett (KNIEZSA I. 1965; 2003b). Hogy mikor melyik képzésmódot ismerhetjük fel a konkrét tövön, azt ilyenkor is csak az adott családnév történetének vizsgálatával deríthetjük ki (VöRös F. 2006). Néhány nyelvészeti szempontot azért figyelembe vehetünk a kérdés megoldásához. Pl. a Gábr- tô a Gáborból jellegzetesen magyaros képzés eredményeként vezethető le, de elvileg szóba jöhet a gyertyán jelentésú szláv gabrz is mint tő (KNIEZSA I. 2003a p. 62). Ez ellen szól, hogy növény nevéből alig keletkezett családnév, illetve a rövidített tô hímnemú alakban ritkán fordul elő a szlovákban (KNIEZSA I. 2003c p. 290). Fontos észrevétel még, hogy a tót nevekben a 12 . század végén fejeződött be a $g>h$ változás, így ma a gyertyán is 
habr-ként szerepel a szótárban (KNIEZSA I. 2003 p. 105). Mivel azonban a családneveink a 14-15 században jöttek létre (KNIEZSA I. 2003a p. 62), Habriš-nak kellene lenni az így képzett névnek. További lehetôség, hogy a magyar Gábor-t a szlovák beszélőközösség (is) -iš képzővel kezdhette használni. Ez különösen kétnyelvű, kettős kultúrájú, illetve identitású környezetben történhetett meg. Jóllehet a fentiek inkább a magyar mellett szólnak, pusztán nyelvi alapon nem lehet élesen elhatárolni egymástól a magyar Gábrist és a szlovák Gabrišt. Ezért hasznosak az extralingvális tényezőket is számba vevő kutatások, mint pl. a családnév alábbiakban bemutatandó földrajzi elterjedésének vizsgálata, amely erôs érv lehet a magyar eredet mellett.

\section{A Gábris név jelenlegi földrajzi elterjedése}

Mint geográfusnak, magától értetődő volt a Gábrisok lakta települések feltérképezése, ami az interneten elérhető telefonkönyvek segítségével látszott megoldhatónak. Magyarországon 51 településen 104 személyt találtam, akiknek a területi megoszlását a 6. ábra mutatja.

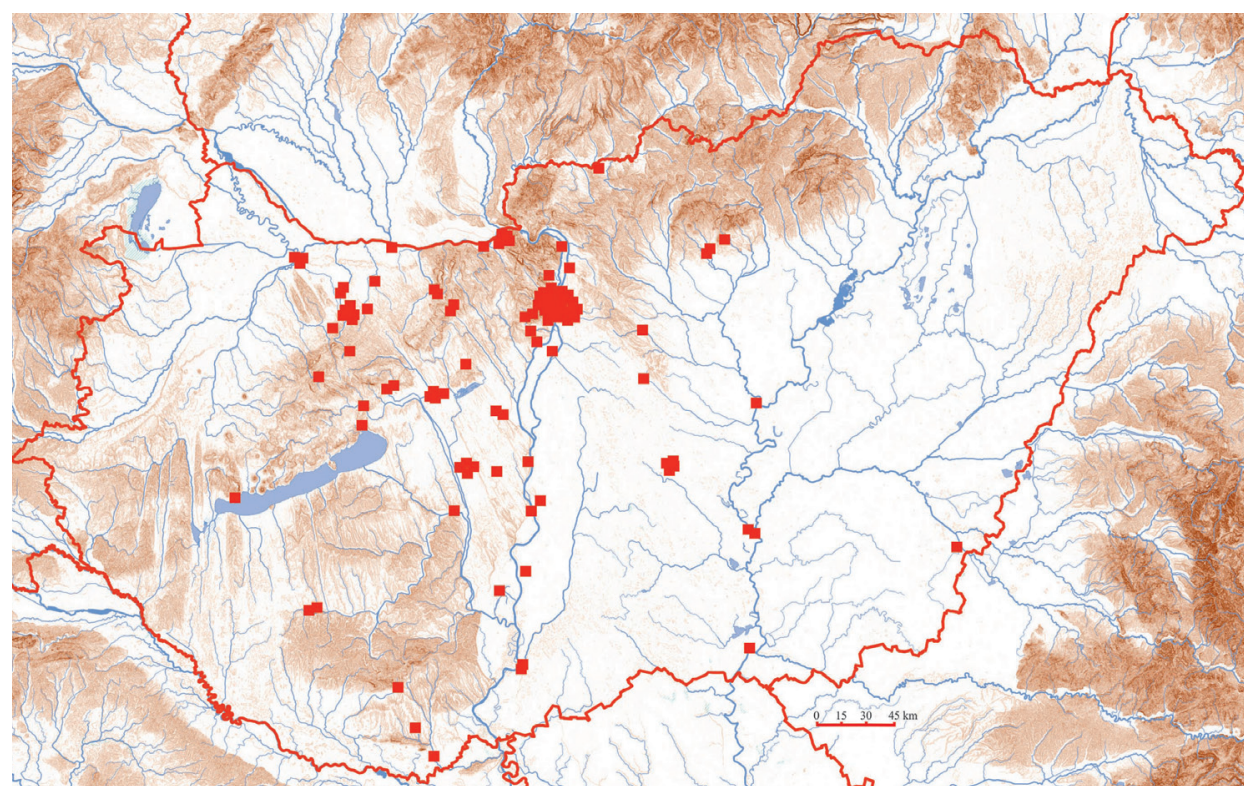

6. ábra A Gábris családnevek előfordulása Magyarországon 2016 (minden piros négyzet egy személyt jelöl a telefonkönyvben) Figure 6 The occurrence of Gábris family names in Hungary 2016 (each red square indicates one person in the phonebook)

A térképen jól látszik, hogy a Kisalföld keleti fele, a hozzá kapcsolódó Bakonyalja, Komárom-Esztergom és Fejér megye a Gábrisok által legsúrúbben lakott, de néhányan innen igen nagy távolságban is élnek (pl. Gyula vagy Bóly). Korábban GÁBRIs GABRIELLA (Szeged) már kísérletezett a telefonkönyv használatával, de a levelével felkeresettek közül nagyon kevesen válaszoltak. Arra mégis jó volt ez az anyag, hogy kiderüljön, sokan más vidékről származnak (a fővárosiak valószínúleg mind), ami a Gábrisok vándorlására, szétszóródására utal. A válaszolók egy része (ha egyáltalán ezt megjelölte) a mai Szlovákia területéről jött, pl. Nagyszombatról, illetve az 1947 júliusa és 1948 nyara közötti szlovákmagyar lakosságcserével (micsoda eufémizmus!) erôsen érintett Szencről vagy Szőgyénről - egy pedig a Délvidékrôl. Szenccel kapcsolatban megjegyzendő, hogy míg 1941-ben a város 
lakosságának 92\%-át, addig 2011-ben már csak 14\%-át adták a magyarok. Ennek ellenére ma Trencsén után a második város, ahol a legtöbb Gábris lakik. Következésképpen Szlovákia internetes telefonkönyvéből (http://telefonny.zoznam.sk), illetve JURAJ ČISARIKnak a szlovákiai állami archívumokban gyújtött családkutatást segítő, saját fejlesztésú internetes adatbázisából (www.cisarik.com) is kigyújtöttem a Gábris (Gabriš) nevűeket. Ez esetben összesen 176 településen 862 személyt találtam, akik települések szerint felkerültek a térképre (7. ábra). HAJDú M. (2010) idézett munkájából kitűnik, hogy a telefonkönyvekben minden harmadik-negyedik családra, általában tíz személyre jut egy vezetékes telefonszám. Ez esetben Magyarországon 300-400 családra, illetve mintegy 1000 személyre, Szlovákiában pedig 3000 családra, nagyjából 8000 személyre vonatkoznak az e módon nyert adatok, így a mintavétel statisztikailag elfogadhatónak túnik az általánosításra.

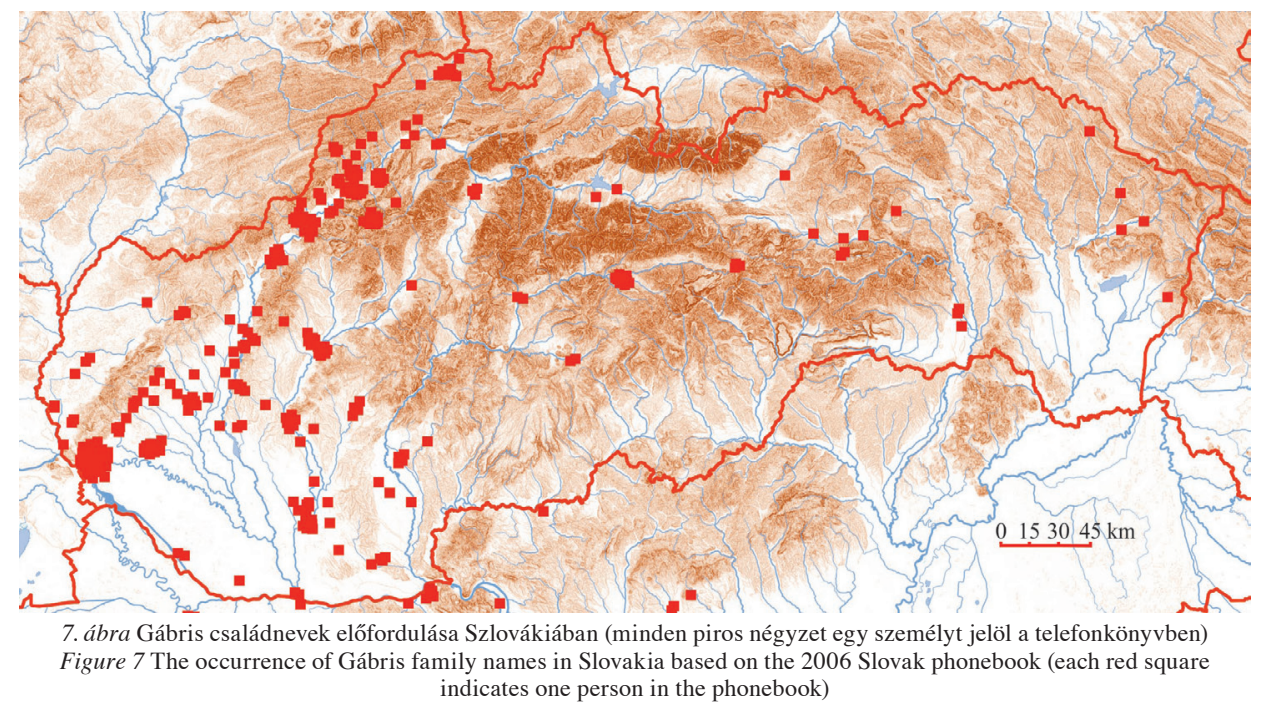

Szlovákiában a döntő többség a mai pozsonyi, nagyszombati, nyitrai és trencséni körzetben lakik, jóllehet keletebbre is előfordulnak. A távolabbi helyek közül megemlítendő néhány ipari város - főként Breznóbánya, kevésbé Kassa -, továbbá a Hernád felső völgye, sőt meglepetésre a keleti végekre, a lengyel és az ukrán határmellékre is eljutottak néhányan. Ha a két térképet összesítjük, és a régi Magyarországban gondolkodunk, akkor kitűnik, hogy Pozsony, Nyitra, Trencsén megye adja a törzsterületet, de Bars, Győr, Komárom, Esztergom, Veszprém és Fejér megye területén is súrúsödnek a jelek.

\section{Idő- és térbeli változások}

A török alól felszabadult országban az adózók számbavétele céljából végzett 1715-1720-as összeírás családnévi adatait VöRös F. (2014) dolgozta fel, s a Gábris nevűek alábbi megyei bontású térképe az Ố szívességéből közölhető (8/A ábra). Kutatásai szerint a 18. század elejétől felgyorsuló természetes és mesterséges migráció sem volt képes alapjaiban fölülírni a családnevek térbeli tagozódását. Az 1720-as és a 2009-es adatbázisok gyakorisági listáit összevetve kimutatta, hogy a 12 leggyakoribb családnév esetében nem változtak meg a történeti névréteg területi arányai. Megállapítja, hogy „a korábbi népességmozgalmak ellenére időbelileg nagyfokú állandóságot mutat a területi tagolódás”. A Gábrisok 
területi elhelyezkedését, vándorlását, terjedésüket további két időkeresztmetszetben sikerült megvizsgálni.

A RadixIndex internetes oldal célja a családfa- és helytörténet kutatásban használható adatbázisok szolgáltatása, melyből két térkép is mutatja az országos elterjedést. Magyarország iparosainak és kereskedőinek 1891-es címjegyzékéből vett adatok alapján készült térkép ( $8 / B$ ábra) határozottan mutatja a bácskai és a torontáli jelenlétet. A listán két Gábrissal szereplő Antalfalvára (Torontál vm.) pl. 1801-1803 között Árva, Trencsén, valamint Békés vármegyéből evangélikus tótok költöztek papjukkal és tanítójukkal együtt. A másik két Gábris a török hódoltság alatt elpusztult Zsombolyán élt, ahová 1766-ban 40, nagyrészt német, beköltöző családot telepítettek le. A három bajai Gábris szintén a betelepülőkkel érkezhetett.

A Verlustliste a Monarchia első világháborús veszteséglistája, amelynek adatbázisa nagyjából $80 \%$-os feldolgozottságon áll. A hiányok ellenére a $8 / C$ ábra jól illeszkedik a korábbi térképek területi megoszlásához. A 8/D ábra pedig a jelenlegi helyzetet mutatja a telefonkönyvek adatbázisa szerint.
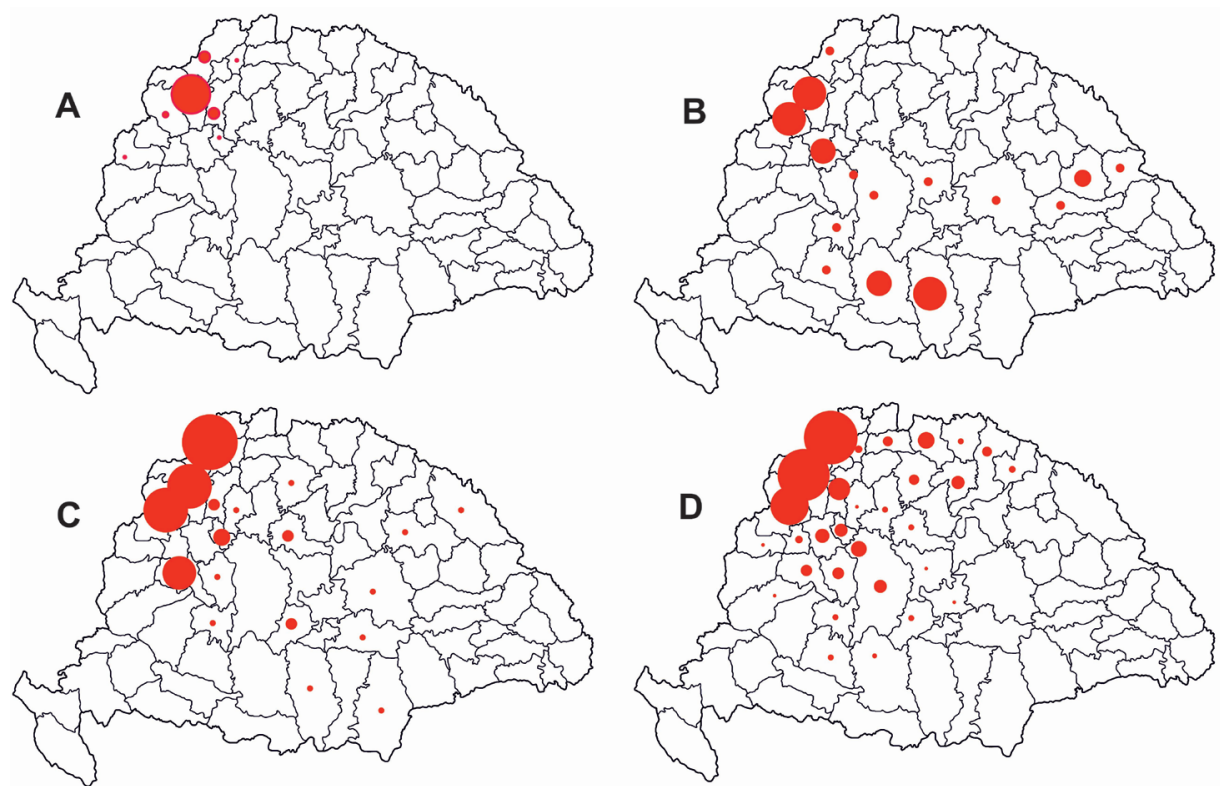

8. ábra Gábrisok térbeli helyzetének változása négy időkeresztmetszetben: A - 1720-as összeírás alapján;

B - iparosok és kereskedők 1891-ben; C - az I. világháborús veszteséglista szerint; D - 21. század eleje

Figure 8 Changing spatial position of the Gábris named persons in four time frame: A - according to the census of 1720 ;

$\mathrm{B}$ - craftsmen and traders in 1891; C - according to World War I loss list; D - beginning of the $21^{\text {st }}$ century

Mint láttuk, nyelvészeti alapon nem dönthető el egyértelmúen a név eredete. Első megközelítésre a földrajz sem segít: mind a történelmi, mind a jelenkori adatok egyaránt azt mutatják, hogy sem a magyar, sem a szlovák nyelvterületen nem általánosan elterjedt a családnév. Viszont az 1720-as összeírás szerint egy jól lehatárolható, a régi ország egészét tekintve kicsiny területen kívül nincsenek Gábris nevűek. Az idősoros térképek alapján egyértelmú, hogy innen, északnyugat felől fokozatosan terjedtek el a csaknem 300 év alatt. A lassú terjedést felülírhatták különleges történelmi helyzetek. Így például figyelmet érdemel a későbbi erôs délvidéki jelenlét, amely a török utáni telepítések hatását mutatja: a 18. században a Felvidék nyugati része felől Bácska és Bánát fontos kirajzási irány volt. 
Kérdés ezek után, hogy kikhez, milyen népcsoporthoz lehet kapcsolni a nevek eredeti hordozóit, ha sem a magyar, sem a szlovák nyelvterület egészére nem jellemző ez a családnév? Történelmi ismereteink szerint nagyjából ezen a területen a honfoglalástól (?) legalább a 13. század második harmadáig jelentős magyarul beszélő (nyugati) székely népesség élt, amit több-kevesebb írott adat is alátámaszt (1. lejjebb). Rekonstruált elterjedésüket GYőRFFY Gy. (1990) térképe mutatja (9A ábra), míg KNIEZSA I. (1938) térképén - Magyarország népei a 11. században - a Gábrisok 18. sz-i előfordulása helyén magyar, vegyes magyar-szláv vagy szláv lakosság van feltüntetve ( $9 B$ ábra), illetve a lakatlan vidékek világos foltjai virítanak. Megjegyzem, nyelvészetileg lehet indokolt, hogy a Morvamező ezen a térképen szlávnak van jelölve a 11. sz-ban, de történelmileg bizonyítható, hogy nem az volt, hanem nagyrészt székelyek lakta terület. Későbbi etnikai változást jelentett a magyarul beszélőknek (a székelyeknek is) Vág menti északra terjedése. KNIEZSA I. (2003b) szerint ugyanis a kettős helynevek vizsgálata alapján Trencsén déli részén már a 10. században, északabbra pedig a 12. század vége előtt igazolható a magyar letelepedés. Szerinte az eredeti szláv falunevekben megőrzött szláv ' $g$ ' (ami tót területeken a 12. század vége előtti átvételre utal) egészen Puchóig megtalálható. E szerint a fennemlített térképen szlávnak jelzett Vág-völgyi szakasz ebben az időben már vegyes magyar-szláv lakosságú volt, és a szlávok feljebb szorultak a völgyben.

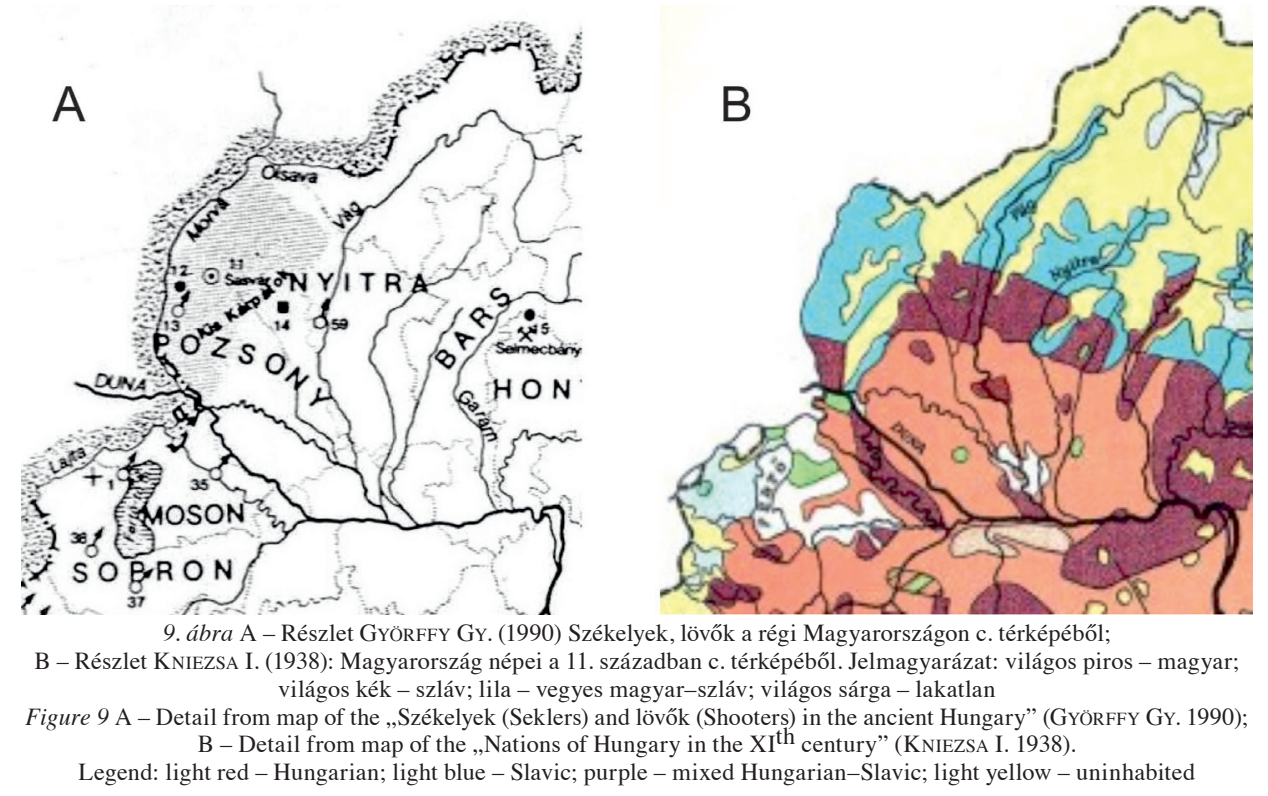

További megfontolandó gondolatok a Gábris családnév magyar (székely) eredete mellett az alábbiak.

a) A Gabr- tő jellegzetesen magyar képzés eredménye (KNIEZSA I. 2003a).

b) Az Imre-Imris, Ábrahám-Ábris, Gábor-Gábris típusú becenevek a székelyek (erdélyiek) között jellegzetes (HEREPEI JÁNOS erdélyi magyar múvelődéstörténész, néprajzkutató szóbeli közlése). (Ehhez hozzávehetjük még a következő adatot, amit Báthory István váradi várkapitány jegyzett fel a családi kalendáriumba: „1589. 15 aug. Gábris vitézt ez nap adta Isten ez világra reggel három és négy óra között.” Báthory Gábor késôbbi erdélyi fejedelemrôl van szó és ez több mint 400 éve történt.) 
c) A 17. század végén teljesen elpusztult, majd fóleg románokkal újra népesített Szilágy megyei Sződemeteren (Săuca) és Tasnádszilvásban (Silvaș) 1715-ben román keresztnévként adatolható a Gabris. Ez arra utalhat, hogy egy szlovák (Trencsén m.) településen és a légvonalban több mint ötszáz km-re fekvő román falvakban előforduló név a magyar nyelvből kerülhetett mindkettőhöz.

d) A madéfalvi veszedelem után a bukovinai Andrásfalvára menekültek, majd a II. világháború után Tolnába költözők között is volt két Gábris család (SEBESTYÉN Á. 1972).

e) A német és a vlach jog alapján (lásd később) telepített falvakba - éppen a keresztnevekból lett családnevek alapján - sokan bekerülhettek a magyarok (székelyek) közül is. Két példa: Trencsénben kilenc ilyen faluban Gábrisok (ebből háromban Gábor is), a szlovák jellegű Árva megyében pedig hét, vlach jog alapján a 16. században vagy az után létesült településén Gábor nevúek élnek. Elgondolkodtató a Juhász családnevúeknek az 1720-as cenzus adataiból kimutatható jelentős előfordulása is Nyitrában, Észak-Trencsénben, Sárosban, Zemplénben és Ungban.

\section{A nyugati székelyekről}

A székelyek a 12. század elejétól szerepelnek forrásainkban, mint a király seregében harcoló könnyúfegyverzetú lovas nép. Első két említésük a nyugati határvidékhez kapcsolódik (SzABAdos Gy. 2007). A Képes Krónika 153. fejezete szól II. István király uralkodása elején (1116) a magyar-cseh (morva) határon levő Olšava folyó (évszázadokig a magyar határt képezte Morvaország felé) mentén zajlott csatájáról. Harminc évvel később, 1146ban II. Géza tekintélyes létszámú serege a Lajta és Fischa folyó (ezek képezték a magyar határt Ausztria felé a 11-15. században) közén megütközött II. Henrik bajor herceg és osztrák őrgróf fegyvereseivel.

A székelyek eredetéről, nevükről eltérő nézetek alakultak ki, de döntően két elképzelés rajzolódik ki (ZELLIGER E. 2009). Az egyik szerint csatlakozott, török eredetú népesség, amely azt a hiedelmet hozta magával, hogy Attila népei közé tartozik, de a magyarokkal való együttélés során nyelvet cserélt. Nyelvészeti szempontból azonban semmi nem szól a nyelvcsere mellett; mert attól kezdve, hogy felbukkannak a leírásokban, mindig magyar nyelvúek. A másik vélemény magyar eredetúnek tartja őket, s mivel a nyugati és a keleti gyepük védelmét látták el, mint határőrök, ezért „,foglalkozást” és nem etnikumot jelent a székely szó. Pl. HunFALVY P. (1890) szerint a székely nem jelent külön népfajt, hanem határőrt, ki bármilyen eredetú lehetett. SzABó K. (1884) okleveleket közölt, melyekből kitúnik, hogy „a vág völgyi székelyek a belső székelyföldről telepíttettek ki, s a királyt fegyverrel szolgáló, épp oly nemesek és szabadok voltak, mint erdélyi székely rokonaik".

Érdekes ENGEL P. (1991) véleménye, aki szerint „csaknem biztosra lehet venni”, hogy magyar etnikumúak voltak, kizártnak tartja, hogy a honfoglaláskor költöztek be, de a magyar törzsektől eltérő, sajátos kapcsolat füzte a türkökhöz (rovásírás), valamint „legegyszerúbb azt gondolni, hogy a késő avarok és a székelyek azonosak. Csatlakozott népként kezelték ôket", tehát a hadjáratok során törvényszerúen az elő-, illetve az utóvéd szerepet kapták, és határok mellé telepítették őket.

Mindegyik nézet képviselői megegyeznek abban, hogy a székelyek határőrök voltak, mégpedig a 11-12. században elsósorban a nyugati, északnyugati végeken, ahol rendszeresek voltak a katonai összecsapások. A honfoglalók (északnyugat felől) a magyar birodalom határául a Morva vizét állapították meg. Azt földvárakkal s más erődítésekkel biztosították és őrizetére besenyőket meg székelyeket rendeltek. A székelység nagy létszámú népesség 
lehetett: első őrtelepei egyrészt a nyugati határvidékeken, Sopron, Moson, Pozsony megye, és a morva határ melletti Sasvár székely ispánság (később Nyitra megye északnyugati része) területén, valamint az Ốrségben voltak, s kiegészítették a besenyő határőrök településhálózatát. Baranyában (vátyi székelyek) is éltek, de többségük a Berettyó és a Körösök völgyét szállta meg. Központjuk Telegd lehetett. Biharból kelet felé nyomulva hatoltak be a 11. században az Erdélyi-medencébe, a 12. században érték el a Hargitát, és a 13. században a KeletiKárpátokat (Borus J. 1985), amelynek szegletében a 13. század közepére alakult ki az a terület, amelyet ma Székelyföldnek nevezünk.

A nyugati székelység kisebb számarányú volt, a 14. századra lassan elvegyült a többi lakos között és nem alakított ki hasonló demográfiai erejü népi tömböt.

A 13. században sûrűsödnek a székelyek említései a nyugati végeken. Néhány példa (JАКАВ E. 1896): II. Endrének 1233-ban és 1234-ben II. Frigyes osztrák herceg ellen viselt győzelmes hadjáratában vettek részt székely lovas íjászok. IV. Béla király a 13. század derekán mondja a Vág-völgyi székelyekről, hogy „oly dicsően harcoltak mellette, hogy mintegy vitézségről vitézségre szállva, királyi lelke megnyugodva gyakran gyönyörködött bennük". Ottokár cseh király 1260-ban panaszolta a pápához írt levelében, hogy ellenfele, IV. Béla király, székelyeket (siculos) és más pogány népeket vitt ellene harcba. Mindezek a nyugati határszéli (mosoni, nyitrai és Vág-vidéki) székelyek lehettek, s úgy túnik, a tatárjárás nem semmisítette meg teljesen a székelyeket, mert jelentős hadra fogható néppel rendelkeztek még ezután is. Tamás esztergomi érsek 1314-ben kiadott bizonyságlevele szerint viszont a Lajta közelében fekvő Barandanbe, vagyis a mai Parndorf helységét már csak „hajdan lakták székelyek" (Székely Oklevéltár III. köt. 7. lap). A keletre költözött székelyek első hadi szerepéről - utólag - IV. Béla 1250. évi oklevele számol be: az 1210 körül lezajlott bulgáriai hadjáratban Joachim szebeni ispán vezetésével szászok, oláhok, székelyek és besenyők Bodon (Vidin) várát foglalták el.

A nyugati székelyek a katonai szolgálat kötelezettségével együtt a királyi várföldekből lakhelyet és birtokot kaptak. Külső támadás esetén egy ideig fel kellett tartaniuk az ellenséget és értesíteni kellett az ispánt és a királyt a támadásról. Közéjük tartoztak a lövők, a portyázó lovas „pásztorkatonák” íjászlovassága. Százakba, hadnagyságba osztották, s legfelsőbb tisztjük a király által kinevezett székely ispán volt. Területileg várispánságot alkottak, mint pl. a Morva síkságán a Sasvári ispánság (Šaštín-Stráže a Miava partján), amelynek közelében lévő telepeik Morvaszentjános (Moravský Svätý Ján), Gajar (Gajary), Kukló (Kuklov) (MAREK, M. 2011), Újvár - Holics (Holíč), Nagy-Lövő (ma Nagylévárd; Vel'ké Leváre), Székelyfalva (Sekule), Bikszárd (Buková) és Konyha (Kuchyňa) lehettek. Ilyen őrségei voltak a Fehér-hegységben (Kis-Kárpátok) a 13. század közepén épült váraknak, mint Detrekő, Korlátkő, Éleskő. A hegységen át vezető utak mentén Szenice, Berezó és Nagyőrvistye lakói is székelyek voltak. A Lysky-hágón a szlovák oldalon levő Strelenka, a cseh oldalon pedig Střelná nevú település eredetileg valószínúleg szintén székely határőrök faluja lehetett (strele jelentése lő; a magyar lővér és lövő településeket székely alapításúaknak tartják; a szlovák levár nevú településeket is általában székely határőrökkel hozzák kapcsolatba).

A hágó felé vezetó út mentén hegyi tanyák nevét is érdemes megvizsgálni. A Lyskyhágó felé vezetô út mentén a vélhetően székely nevet őző Siekel' családnév mellett Gábovci, és szomszédságában egy Barnovci (Barna) név is feltûnik. A Siekel' név a 14. század elején a vlach jog szerint alapított falu, Valaská Belá (Bélapataka, Nyitra vármegye) külterületén is előfordul. Az északnyugati határszélen, az egyik legfontosabb hágóhoz vezetô út menti Csaca közelében Gáborovci tûnik fel a térképen. Nyilván ezek az esetek legfeljebb arról tanúskodhatnak, hogy a hegyvidéki zárt erôterületekbe felhúzódó, „vlach” telepítés-hullámba keveredve, feltűnnek olyan családnevek is, amelyek eredete összefügghet 
a székelyekkel (FARKAS GYÖRGY - ELTE Társadalom- és Gazdaságföldrajzi Tanszék szóbeli közlése).

A Vág mellett Vágszerdahely (ma Alsószerdahely) és főleg Vága, aztán Vágbeszterce, Diós (ma Alsódiós) és Vágőr (Krakovány része) meg az alább említendő Boleráz, illetve messze északon a Zsolnai járásbeli Nemesőr (Stráža), valamint a köztudatból kiveszett más helyek maradtak meg, mint lakóhelyeik. A 11. században létező határispánságok azonban a következő két évszázadban megszűntek vagy beolvadtak a királyi vármegyerendszerbe. Ilyen megszúnt határispánság székhelye volt északnyugaton Sasváron kívül Stomfa, beljebb pedig Bánya (Banka, teljes nevén Árkibánya, ma Pöstyén része), Galgóc, Szolgagyőr (ma Udvarnok) és Sempte. A nagyobb várispánságok, mint Pozsony, Nyitra, Bolondóc (Beckó) és Trencsén körül szintén lakhatott ilyen katonaság. A várrendszer megszúnése a székely telepeket is eltemette. Ennek oka lehet, hogy különböző jogi helyzetben voltak: a nyugati székelyek közt voltak szolgák és voltak várjobbágyi szabadságot élvezők, és nincs tudomásunk arról, hogy egységes, közös szabadságjoggal rendelkeztek volna, mint a keletiek. Azt, hogy ,az őrtelepekből többet s nagyobb bizonyossággal nem ismerünk, hogy szervezetüket és régi alakjukat, a vág-völgyi székely ispán jogkörét nem tudjuk, a hatósága alatt volt fegyveres nép számát illető adatok elpusztultak, s az ott király nemeseiként katonáskodott székelység legtöbb helyen csak, mint sejtelem él, egyedül Vágán (Váhovce) maradt fenn rá ismerhetőleg, sajnálhatjuk, nyomozhatjuk tovább is. De most világosságra derítni nem tudjuk" (JAKAB E. 1896).

Az etnikai viszonyok az idők folyamán részben lassan változtak, így a sasvári székely lövők beolvadtak a Morva mentén tömegesen jött szláv telepesekbe (GYôRFFY GY. 1998), de a történelem tragikus eseményei is nagy szerepet játszottak az eredeti lakosság megcsappanásában. A tatárjárás idején a Lengyel- és Morvaországon átgázoló tatárok Orda és Bajdar vezetésével Trencsénnél a Vlára-szoroson át betörtek az országba, nagy pusztítást végeztek a Dunától északra levô részeken (Nyitra, Komárom és Pozsony megyében), de Trencsén, Nyitra és Pozsony várait elfoglalni nem tudták. Aztán főleg a török időkben, de Bethlen Gábor és Rákóczi Ferenc Habsburg-ellenes háborúiban is nagy volt a lakosság vesztesége. Tényszerúen ismert, hogy a II. világháború utáni lakosságcsere során Gábrisokat is kitelepítettek Magyarországra, de ennek mértékéről nincs adatunk.

Mindezek fényében érdemes összevetni a fentebb említett adatbázis szerint a Gábrisok földrajzi elterjedését a valamikori északnyugati határvidéken az írásos adatok alapján az Árpád-korban határőrök lakta települések és ispánsági várak (10. ábra) helyzetével, valamint a folyók-hegyek-utak rendszerével. Ma Gábris nevú lakosok élnek a térképen négyzetek jelölte településekben (egy négyzet egy telefonszámot jelent).

A fent említett Boleráz abban a vonalban van, amelyben a Kis-Kárpátok belső oldalán, a hegyekből lefutó patakok mentén kialakult településsorozatot a hegység lábánál levő erdőhatárral párhuzamos út füzi fel. A hegységen átvezető hágóknál, és túloldalon - a Morva menti síkságon - néhány stratégiailag fontos településen is van jel.Ezek mind olyan helyek, amelyek a határok ôrzésével megbízottak letelepedésére alkalmasak lehettek. Egy északabbi „,határkapu” is van - Szenice és Berezó között -, ahol székelyek őrizték a hágót (mindkét helyen vannak Gábris nevű lakosok). Hasonló a helyzet a Vág mentén Trencséntől folyamatosan észak felé, ahol az összekötő völgyi főutak és a hágók felé vezető átkelő mellékutak mentén sorakoznak a falvak, bennük Gábris nevú lakosokkal. Megjegyzendő, hogy KNIEZSA I. (2003) szerint Trencséntől északra egészen Puchóig már a 12. század vége előtt igazolható a magyar letelepedés, a Vág-völgy ezen szakasza ekkortól már vegyes magyarszláv lakosságú volt. Érdekes összefüggésre utalhat, hogy ma összesen 30 olyan település van Szlovákiában - nagyrészt a Vág völgyében és a Kisalföldön - amelyben Gábris és Gábor nevú lakos egyaránt él. 


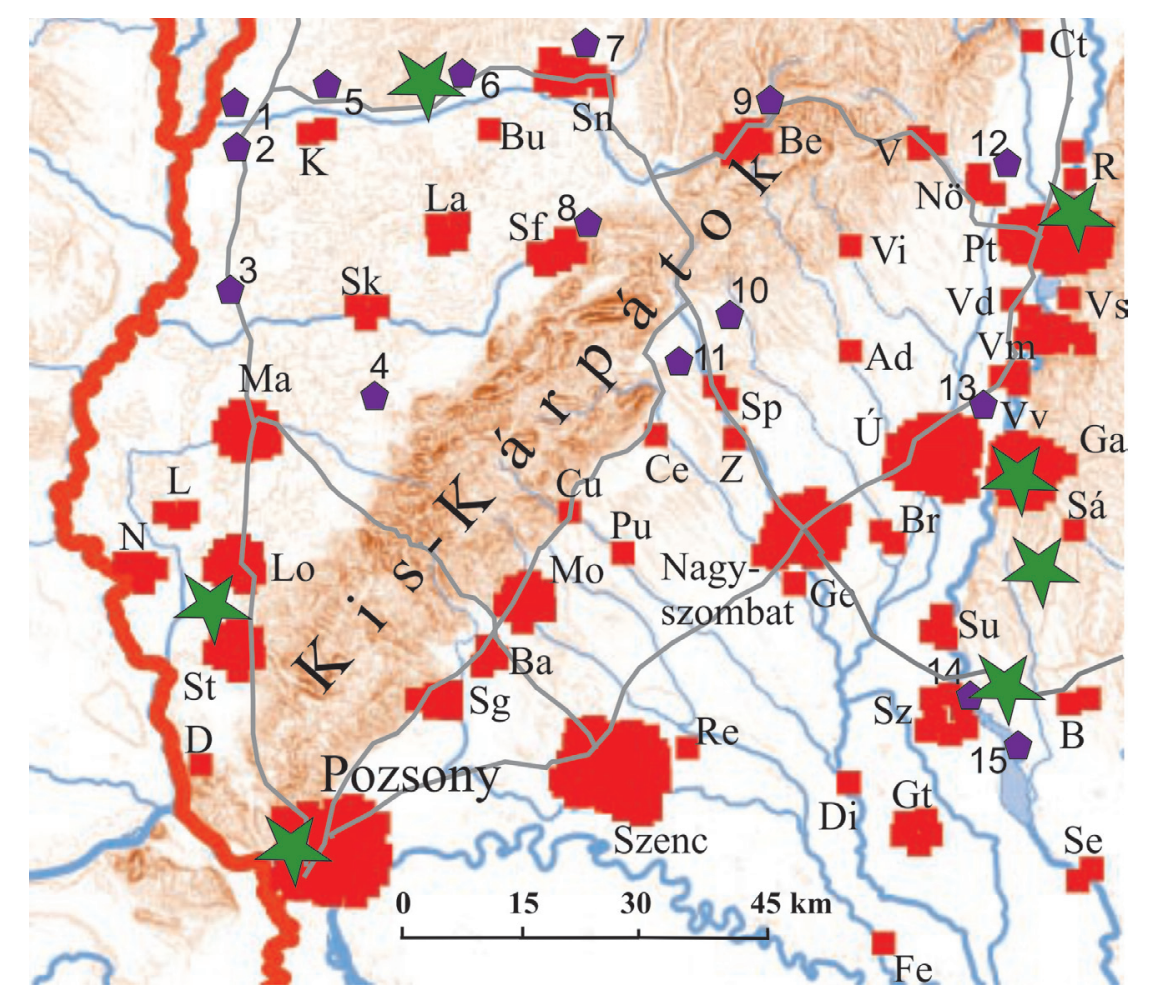

10. ábra Gábris családnevek az ÉNy-i határvidéken, Pozsony és Nyitra megyében (lila ötszög jelzi az Árpád korban határoorök lakta településeket, a zöld csillag pedig az ispánságok várait)

Figure 10 Gábris named persons in the NW border area of the ancient Hungary, former Pozsony and Nyitra counties (purple pentagon indicates the settlements inhabited by border guards [Seklers] in the Ârpád Age, and the green star marks the castles of the Royal Constable).

Települések (Settlements): Ad - Alsódombó (Dolné Dubové); B - Báb (Báb); Ba - Bazin (Pezinok);

Be - Berezó (Brezová pod Bradlom); Br - Bresztovány (Brestovany); Bu - Búrszentmiklós (Borský Mikuláš);

Ce - Cseszte (Častá); Ct - Csejte (Čachtice); Cu - Cserfalu (Dubova); D - Dévényújfalu (Devínska Nová Ves); $\mathrm{Di}$ - Diószeg (Sládkovičovo); Fe - Feketenyék (Čierna Voda); Ga - Galgóc (Hlohovec);

Ge - Gerencsér (Hrnčiarovce nad Parnou); Gt - Galánta (Galanta); K - Kukló (Kuklov); L - Láb (Láb);

La - Laksárújfalu (LakDarska Nová Ves); Lo - Lozornó (Lozorno); Ma - Malacka (Malacky); Mo - Modor (Modra);

N - Nagymagasfalu (Vysoká pri Morave); Nö - Nagyörvistye (Vel'ké Orvište); Pt - Pöstyén (Piešt’any);

$\mathrm{Pu}$ - Pudmericz (Budmerice); R - Ratnóc (Ratnovce); Re - Réte (Reca); Sá - Ság (Sasinkovo); Sf - Sándorfa (Prievaly);

Se - Vágsellye (Šal’a); Sg - Szentgyörgy (Svätý Jur); Sp - Szárazpatak, Szuha (Suchá nad Parnou);

Sk - Szentistvánkút, Szentistván (Studienka); Sn - Szenice (Senica); St - Stomfa (Stupava); Sz - Szered (Sered');

Su - Súr (Š́́rovce); Ú - Újvároska (Leopoldov); V - Verbó (Vrbové); Vd - Vágdebrőd (Drahovce);

Vi - Vittenc (Chtelnica); Vl - Vágluka (Lúka); Vm - Vágmedence (Madunice); Vs - Vágszakaly (Sokolovce); Vv - Vágvörösvár (Červeník); Z - Zvoncsin, Harangfalva (Zvončin).

Székely falvak (Sekler villages): 1 Székelyfalva (Sekule); 2 Morvaszentjános (Moravský Ján); 3 Nagylévárd (azelőtt

Nagylövő, Vel'ké Leváre); 4 Konyha (Kuchyňa); 5 Morvaoor (Stráže); 6 Sasvár (Šaštín); 7 Szenice (Senica);

8 Bikszárd (Buková); 9 Berezó (Brezová pod Bradlom); 10 Boleráz (Boleráz); 11 Alsódiós (Dolné Ore[any);

12 Vágőr (Stráže); 13 Vágvörösvár (Červeník) 14 Vága (Váhovce); 15 Vágszerdahely (Dolná Streda).

A Vág völgyében és az északnyugati (régi határ menti) hegyekben is nagyon sok településen lakik Gábris nevú család (11.ábra). Ezeknek a falvaknak jelentős része azonban későbbi telepítés, vagy újratelepítés, mégpedig a német, illetve a vlach jog alapján. Az előbbiek ún. irtványfalvak, amelyeket scultetus (skultéti), illetve Schultheiss (sulteisz, soltész) vezetésével telepítettek ritkán lakott, általában erdős területen. A telepesek a szolga állapottal szemben szabad jogállásúak voltak. Az irtásért 10-12 éves adómentességet kaptak, azután pedig pontosan - gyakran pénzben - meghatározott földesúri járadékot fizettek, és 


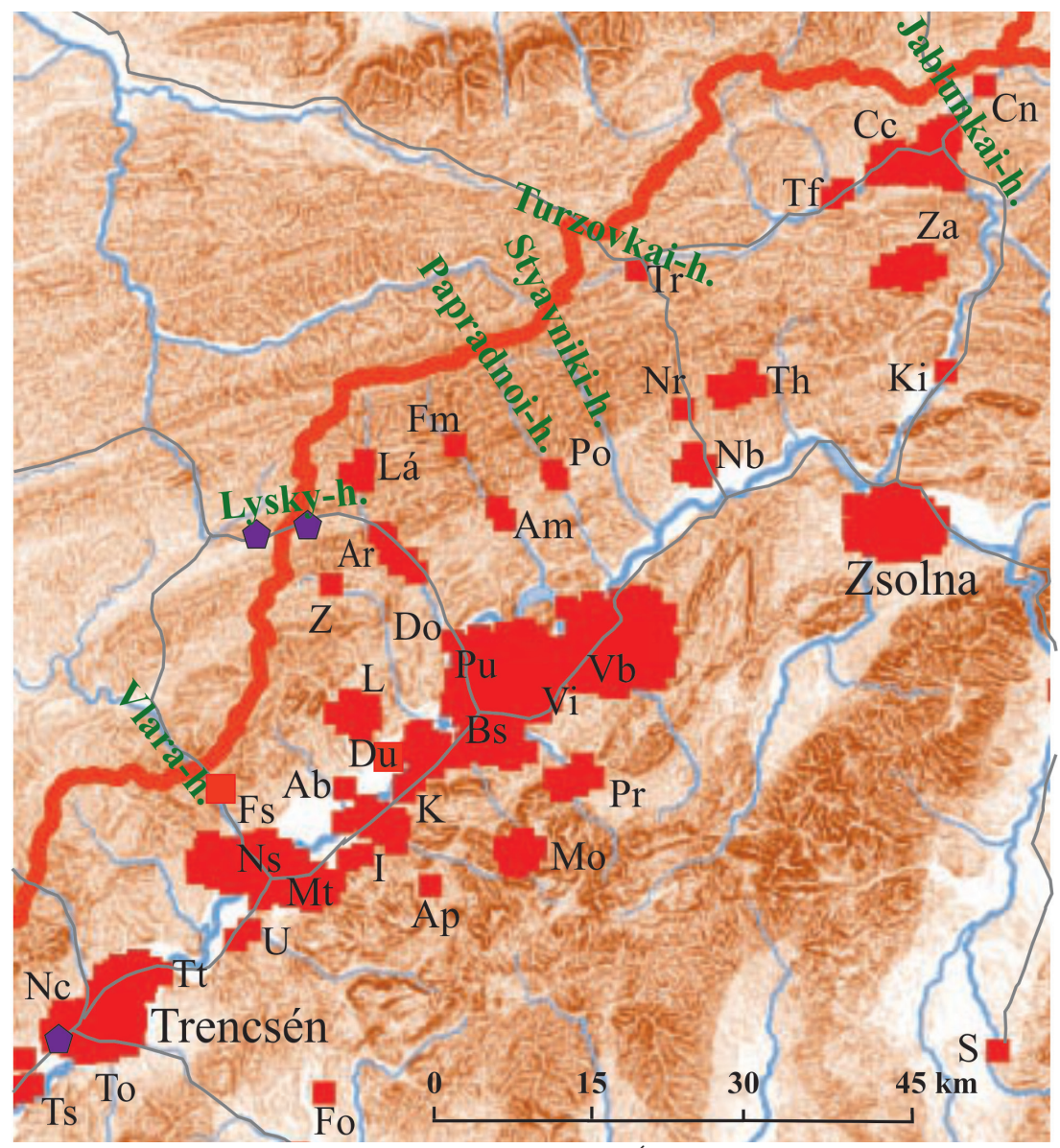

11. ábra Gábris nevúek a Vág völgye mentén (lila ötszög jelzi az Árpád-korban határőrök lakta településeket) Figure 11 Gábris named persons along the valley of the Vág

(purple pentagon indicates the settlements inhabited by border guards [Seklers] in the Árpád Age).

Települések (Settlements): Ab - Alsóbreznic (Dolná Breznica); Am - Alsómarikó (Dolná Mariková); Ap - Alsóporubka (Dolná Poruba); Ar - Alsórétfalu (Lúky); Bs - Bellus (Beluša); Cc - Csaca (Čadca); Cn - Cserne (Čierne); Do - Donány (Dohňany); Du - Dúlóújfalu (Dulov); Fm - Felsőmarikó (Horná Mariková);

Fo - Felsốozor (Horné Ozorovce); Fs - Felsőszernye (Horné Srnie); I - Illava (Ilava); K - Kasza (Košeca);

Ki - Kiszucaújhely (Kysucké Nové Mesto); Ko - Kotessó (Koteロvá); L - Lednicróna (Lednické Rovne);

Lá - Láz (Laz); Mo - Majtény (Mojtín); Mt - Máriatölgyes (Dubnica nad Váhom); Nb - Nagybiccse (Bytča);

Nc - Nagybiróc (Vel'ké Bierovce); Nr - Nagyróna (Vel'ké Rovné); Ns - Nemsó (Nemšová); Po - Papradnó (Papradno); $\mathrm{Pr}$ - Pruzsina (Pružina); Pu - Puhó (Púchov); S - Stubnyafürdő (Turčianske Teplice);

To - Tornyos (Turna, Trenčianska Turná); Th - Trencsénhosszúmező (Dlhé Pole); Tr - Trencsénrákó (Raková);

Ts - Trencsénsztankóc (Trenčianske Stankovce); Tt - Trencsénteplic (Trenčianska Teplá); Tf - Turzófalva (Turzovka); Tz - Trencsénzávod (Trenčianska Závada); U - Újtölgyes, (Nová Dubnica);

Vb - Vágbeszterce (Považská Bystrica); Vi - Viszolaj (Visolaje); Z - Trencsénfogas (Zubak); Za - Zakopcse (Zákopčie)

a telkek szabad forgalma jellemezte óket. A német jog alapján alapítottak közül ma Gábris nevú lakosa van Alsómarikónak (1321), Alsórétfalunak (1471), és a későbben újratelepített Majténynak (1633) is. A mai Szlovákia benépesülésének másik lényeges eleme volt az északi, nehezen múvelhető hegyvidék betelepítése a vlach jog alapján. A transzhumáló (legelőváltós) életmódot folytató pásztorkodó népesség (a Felvidéken nem oláh [vlach], hanem ruszin és tót, esetleg magyar [székely]) kezdetben a már meglevő falvak környékén 
telepedett meg, mint pl. Csaca (1417) és Felsőszernye (1546) esetében. Később azonban már önálló településeket is alapítottak, mint Nagyróna (1546-1554 között), Turzófalva (1580), Trencsénrákó (17. század első fele), Cserne (1641 előtt). A példák minden esetben azok a települések (zárójelben az alapítás évével), melyekben van Gábris nevú lakos (12. ábra). Elgondolkoztató adalék, hogy 23 ilyen telepítésű faluban Gábor nevűek is laknak.

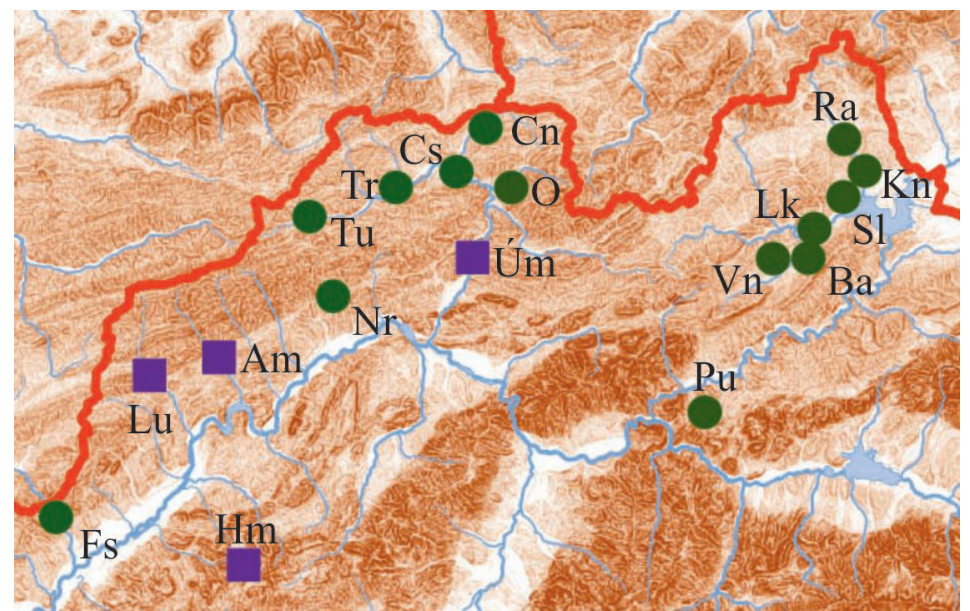

12. ábra Gábor, Gábris vagy mindkét nevúek lakta, német jog (lila négyzet) és vlach jog szerint (zöld kör) alapított települések Trencsén és Árva megyékben

Figure 12 Settlements founded by German law (purple square) and Vlach law (green circle), inhabited by Gábor, Gábris or both in counties Trencsén and Árva

Települések (Settlements): a) vlach jog szerint (under Vlach law): Ba - Babin (Babín); Cn - Cserne (Čierne pri Čadci); Cs - Csaca (Čadca); Fs - Felsőszernye (Horné Sŕnie); Kn - Klin (Klin); Lk - Lókca (Lokca);

Nr - Nagyróna (Vel’ké Rovné); O - Ócsad (Oščadnica); Pu - Pucó (Pucov); Ra - Rapcsa (Rabča);

Sl - Szlanica (Slanica, Námestovo része); Tr - Trencsénrákó (Raková); Tu - Turzófalva (Turzovka);

Vn - Vanyovka (Vaňovka). b) Német jog szerint (under German law): Am - Alsómarikó (Dolná Mariková);

Hm - Hegyesmajtény (Mojtín); Lu - Lúki, Alsórétfalu (Lúky); Úm - Újhelymogyoród (Kysucký Lieskovec)

Nem bizonyítható, sőt nem is feltételezhető, hogy 700-800 év óta folyamatosan egy helyben laknának a székely határőrök körében sajátos névadással elnevezett, de több őstől is származó Gábrisok. Jóllehet néhány eredetileg székelyek lakta településben - Berezó, Galánta, Kukló, Nagyőrvistye, Stomfa, Szenice, Szered, Vágbeszterce - ma is élnek Gábrisok. Az elvándorlás, költözés normális dolog lehetett, amelyet érdemes lenne megvizsgálni, legalábbis abban a mintegy 300 évben, amelyról vannak név szerinti adataink.

Egy esetben azonban egy csaknem 400 éves helyben lakás mégis bizonyítható, s ez éppen Gábris László, a császár legöregebb katonája esetén derült ki, aki Mojtín (Hegyesmajtény) nevú faluban született 1738-ban. A település első említése (Motie) ugyan 1208-ból származik, de a 16. században és a 17. elején nem említik, valószínúleg lakatlanná vált. A mai falu úgy keletkezett, hogy 1633-ban három másikkal együtt a Gábris családot a Vág folyó járvány (pestis) pusztította középső szakaszáról ide telepítette a terület földesura (SAFÁRY E.-ZACHAR E. 1992), abból a célból, hogy ezeket a területeket is múvelésbe vonják. Ebból a családból került ki a település első falubírája (a skultéti), László ükapja, s aztán valószínúleg dédapja és nagyapja is. A betelepülő közösség az erdőirtásért és letelepedésért cserébe különböző kiváltságokat élvezett, például több évre adómentességet kaptak. Vezetőjük, a skultéti a továbbiakban sem adózott (az 1720-as összeírásban valószínúleg ezért nem szerepel itt Gábris), sőt jogot formálhatott a telepes közösség adójának egy részére, bíráskodhatott, telek- és földtulajdona, kocsma- és malomtartási joga lehetett (László apja 
mielőtt katonának állt volna, molnár volt). A cím és az ezzel járó kiváltságok örökíthetők voltak apáról fiúra. Ebből származhatott, öröklődhetett a skultéti elnevezés (ragadványnév) az egyenes ági leszármazottakra (pl. a bíró testvéreitől származókra nem), amely a későbbiekben a huszár megkülönböztető, felvett családi nevévé vált a katonaságnál (apján kívül még egy Gábris szolgált az ezredében). Így Gábris Lászlónak nincs köze a Skultéty nevú családokhoz. Ma is élnek itt a család leszármazottai, például a község polgármestere (bírája), Eva Gabrišová. A szomszéd Pruzsinán is több Gábris lakik, sőt Mojtíntól beljebb, a hegységi erdőben egy kicsiny zsákfalu neve Gabrišovci.

Az új telepítésú falvakban és sok régiben is a szlovák, illetve az időközbeni lakosságcsere útján más szláv (pl. horvát) nyelvi környezetbe kerülő Gábris családok lassan elveszthették nyelvüket, hosszabb idő után nemzeti azonosságtudatukat is. (A jelenleg Gábrisok lakta Berezó, Cserfalu, Cseszte, Dévényújfalu, Nagymagasfalu, Vittenc, Zvoncsin falvakba a 16. sz. ötvenes éveiben nagy számban települtek le a délvidékről menekülő horvátok. Vittencben például a 20. század elején még többen tartották is horvát nemzetiségüket.)

A régi Magyarország egészére sajnos nem sikerült kiterjeszteni a vizsgálatokat. Romániából a jelenleg hozzáférhető megyei telefonkönyvekben csupán 12 Gábris található Erdélyben és a tágabb értelemben vett Partiumban. Ismeretlen a délvidéki jelenlét mértéke és helyzete is, szintén a megbízható adatbázis híján. Az Őrvidékre ugyancsak székely határőrök települtek, határispánságuk központja a Felsőpulya melletti Locsmánd volt. Ausztriában ma 16 Gabris (Gabrisch) szerepel a telefonkönyvben, s ebból 9 Bécsben lakik, Bécshez közeli településen egy, Graz mellett kettő, Illmitzben, Salzburgban és Welsben egy-egy; tehát jellegtelen földrajzi eloszlásban élnek. A 27 Gáborból négyen laknak Burgenlandban, vagyis a régi ország területén. A többiek nagyrészt a Duna mentén, de általában jellegtelen elszórtságban.

\section{Összefoglalás}

A nyelvföldrajz a nyelv térbeliséget vizsgálja. A magyar (földrajzi) hely- és személynevek, valamint a törzsnevek vizsgálata mintegy másfél évszázadra tekint vissza. A mai névföldrajz azonban csak a digitális adatbázisok és a számítógéppel támogatott kartográfia segítségével bontakozott ki. Földrajzosok alig foglalkoznak a nyelvi jelenségek térbeliségének kutatásával. A tanulmány erre vonatkozó kísérletet jelent, példaképpen a Gábor családnév, illetve névváltozatainak földrajzi és történelmi összefüggések keretében történő vizsgálatával.

A 15. század közepétől, illetve a 16. század elejétől öröklődő magyar eredetű családneveink között igen gyakori és egyben a legrégebb óta előforduló az apai személynévből, vagy annak becézett változatából alakult típus. Ilyen a Gábor családnév, amelynek térbeli megoszlását, időbeli változásait mutatja be a tanulmány, különös figyelemmel a történelmi, politikai hatásokra. A kutatás alapjául három adatbázis szolgált: az oszmán uralom alól teljesen felszabadult ország első összeírása az adózók számbavétele céljából (1720); a RadixIndex (Adatbázisok családfa- és helytörténet-kutatóknak) első világháborús veszteséglistájának (Verlustliste) internetes adatbázisa; valamint a magyar, a szlovák és az osztrák internetes telefonkönyv adatai (Romániából és Szerbiából nincs adat).

GÁBRIS GYULA

ELTE TTK Természetföldrajzi Tanszék, Budapest

gabris@ttk.elte.hu 


\section{IRODALOM}

BENKŐ L. 1949: A történeti személynévvizsgálat kérdései II. - Magyar Nyelv 45. 3. pp. 244-256.

BoRus J. (szerk.) 1985: Magyarország hadtörténete I. A honfoglalástól a kiegyezésig. - Zrínyi Katonai Kiadó, Budapest. $670 \mathrm{p}$.

DÁvid Z. 1957: Az 1715-20. évi összeírás. - In: KovACsics J. (szerk.): A történeti statisztika forrásai. Közgazdasági és Jogi Kiadó, Budapest. pp. 145-199.

EGYED Á. 2006: A székelyek rövid története a megtelepedéstől 1918-ig. - Pallas Akadémia, Csíkszereda. 318.p.

ENGEL P. 1991: Beilleszkedés Európába, kezdetektől 1440-ig. - Háttér Lap- és Könyvkiadó, Budapest. 388 p.

GÁBRIs Gy. 2016: Egy családnév földrajzi és történelmi háttere. - In: VöRös F. (szerk.): Névregionalizmusok. A nyelvföldrajztól a névföldrajzig VII. Savaria University Press, Szombathely. pp. 125-144.

GÁBRIS GY. 2017: Gábor, Mihály és Rafael családnevek nyelvföldrajzának időszeletei. - In: VöRÖs F. (szerk.): A nyelvterület keleti peremén. A nyelvföldrajztól a névföldrajzig VIII. Erdélyi Múzeum Egyesület és Savaria University Press, Kolozsvár-Szombathely. pp. 141-160.

GYÖRFFY GY. 1941: A székelyek eredete és településük története. - In: GYÖRFFY GY. 1990: A magyarság keleti elemei. Gondolat Kiadó, Budapest. pp. 37-86.

GYőRFFY Gy. 1998: Az Árpád-kori Magyarország történeti földrajza IV. - Akadémiai Kiadó, Budapest. 714 p.

HAJdú M. 2010: Családnevek enciklopédiája. Leggyakoribb mai családneveink. - Tinta Könyvkiadó, Budapest. $458 \mathrm{p}$.

Hunfalvy P. 1890: Ethnographia I. pp. 361-362.

JAKAB E. 1896: Székely telepek Magyarországon. - Századok 30. 7. pp. 581-606. és 30. 8. pp. 693-704.

KÁZMÉr M. 1993: Régi magyar családnevek szótára. XIV-XVII. század. - Magyar Nyelvtudományi Társaság, Budapest. 1172 p.

KNIEZSA I. 1965: A magyar és szlovák családnevek rendszere. - Eötvös Loránd Tudományegyetem, Budapest. 112 p.

KNIEZSA I. 2003a: Az Ecsedi-láp környékének szláv eredetű helynevei. - In: KNIEZsA I.: Helynév- és családnév-vizsgálatok. Lucidus Kiadó, Budapest. pp. 59-108.

KnIEZSA I. 2003b: A párhuzamos helynévadás.- In: KNIEZSA I.: Helynév- és családnév-vizsgálatok. Lucidus Kiadó, Budapest. pp. 115-167.

KNIEZSA I. 2003c: A magyar és a szlovák családnevek rendszere. - In: KNIEZSA I.: Helynév- és családnév-vizsgálatok. Lucidus Kiadó, Budapest. pp. 255-348.

KoCSIS K.-TÁTRAI P. 2013: A Kárpát-Pannon térség változó etnikai arculata.-MTA CSFK Földrajztudományi Intézet. CD kiadvány.

MareK, M. 2011: Národnosti Uhorska. - Filozofická fakulta Trnavskej univerzity v Trnave. 459. p.

Mező A. 1970: Várdai birtokok jobbágynevei a XV. század közepén. - Kisvárdai Múzeum Kiadványai, Kisvárda. 42 p.

N. FoDOR J. 2014: Névföldrajz és etimológia. Mutatvány a Történeti magyar családnévatlasz lexikális térképlapjaiból. - Magyar Nyelvőr 138. 4. pp. 451-460.

PÁLFFY G. 2009: Romlás és megújulás (1606-1703). - Kossuth Kiadó, Budapest. 112 p.

SAFÁRY E.-ZACHAR E. 1992: Nyolcvan nyár nyeregben. - IKVA Kft. Sopron. 151 p.

SEBESTYÉn Á. 1972: A bukovinai andrásfalvi székelyek élete és története Madéfalvától napjainkig. - Tolna megyei Tanács VB. Múvelődésügyi Osztálya, Szekszárd. 280 p.

SzaBAdos Gy. 2007: A 12. századi magyar hadtörténet forrásproblémáiból. - Aetas 22. 4. pp. 153-160.

SzABó I. 1954: Bács, Bodrog és Csongrád megyei dézsmalajstromai. - Magyar Nyelvtudományi Társaság Kiadványai 86.84 p.

SzABó K. 1884: Királyi telepítvényesek-é a székelyek? - In: A székely mivelödési és gazdasági egylet Marosvásárhelyt, 1884. évi szeptember hó 25-én tartott nagygyưlésének emlékkönyve. Marosvásárhely. 33 p.

Történeti magyar családnévatlasz. - http://www.csaladnevatlasz.hu/

VÖRÖS F. 2006: Gondolatok a magyar és a szlovák családnevek összevetéséhez. - Névtani Értesítő 28. pp. 45-54.

VÖRÖs F. 2010: Mutatvány a mai magyar családnévatlasz előmunkálataiból. - Magyar Nyelv 106. 2.pp. 159-169 és 106. 3. pp. 308-321.

Vörös F. 2014: Kis magyar családnévatlasz. - Kalligram Kiadó, Pozsony. 240 p. (főszerk.): Magyarország története 1686-1790. - Akadémiai Kiadó, Budapest. pp. 25-80.

ZELliger E. 2010: Az Óperenciás-tengeren innen és túl. Magyar vonatkozású nevek nyomában. - Magyar Nyelv 106. 3. pp. 283-295. 